7. Nguyễn Văn Hai, Lê Trung Hải (2009). Đặc điểm lâm sàng, bệnh kết hợp và chân đoán viêm ruột thừa cấp ở người cao tuổi. Tap chí học thực hành. 11, 88-91.

8. Kim Văn Vụ (2011). Đặc điểm lâm sàng, cận lâm sàng viêm ruột thừa sau manh tràng điêu trị tại bệnh viện Đại học Y Hà Nội. Tạp chí y học thực hành. 11, 64-66.

9. Tống Thị Thu Hằng (2006). Nghiên cứu một số đặc điểm lâm sàng và giải phâuu bênh của viêm ruột thữa cấp, Khóa luấn Tốt nghiệp Bác sĩ đa khoa Trường Đại học Y Hà Nội, Hà Nội.

\title{
SỐC TIM DO HẠ CANXI MÁU NẶNG Ở TRẺ BÚ MẸ
}

\section{TÓM TẮT}

Ha canxi máu nặng là một tình trạng cấp cứu có thể gầy rối loạn nhịp tim, giảm sức co bóp cơ tim và có thể dẫn đến sốc tim, thậm chí tử vong ở trẻ em. Do đó, trên lâm sàng hạ canxi máu nặng là tình trạng cân đước phát hiên và xử trí kip thời. Mục tiêu: Mổ tả đăc điểm lâm sàng, xét nghiệm hóa sinh, thăm dò chức năng tim và xứ trí đối với bệnh nhân sốc tim do ha canxi máu nặng. Đối tượng: 3 bệnh nhân được chẩn đoán hạ canxi máu nă̆ng có biểu hiện rối loạn chức năng co bóp cơ tim trên lâm sàng tại Bệnh viện Nhi Trung ương. Phương pháp: Nghiên cưuu một loạt ca bệnh bao gồm triệu chứng lâm sàng, tiền sử, chức nẳng tim mạch và kết quả điêu trị. Kết quả: 2 trong số 3 trường hợp biểu hiện sốc tim trên lâm sàng. 3 trường hợp trẻ đều có tình trạng suy giảm chức năng tâm thu thất trái, 2/3 trường hợp có rối loạn điện tâm đồ với khoảng QT kéo dài. Xét nghiệm hóa sinh cho thấy cả 3 trẻ có tình trạng hạ canxi máu nặng và thiếu Vitamin D. Kết luận: Trong cả 3 trường hợp, hạ canxi máu là nguyên nhân duy nhất tìm thấy có liên quan đến rối loạn chức năng tim mạch. Điều trị bằng truyền canxi tĩnh mạch, bổ sung Vitamin $D$, caltriol và canxi giúp hồi phuc hoàn toàn chức năng cớ tim.

Tư khóa: Ha canxi máu nặng trẻ em, sốc tim do hạ canxi máu, rối loạn nhịp tim do hạ canxi máu.

\section{SUMMARY \\ CARDIOGENIC SHOCK IN INFANTS WITH} SEVERE HYPOCALCINEMIA

Severe hypocalcemia is a life-threatening condition that causes serious consequences including cardiomyocytes, which leads to a reduction of cardiomyocyte contractile, arrhythmias, and cardiogenic shock even death in children. It is a serious condition that should be diagnosed and treated promptly. Objectives: to describe clinical characteristics, cardiac function tests, and to approach treatment to patients with hypocalcemia-induced cardiogenic shock. Subjects: 3 patients were diagnosed with severe hypocalcemia, accompanied by a reduction of cardiomyocyte contractile treated at The Vietnam National Children's Hospital. Method: A

*Bênh viên Nhi Trung Uơng

Chịu trách nhiệm chính: Vũ Chí Dũng

Email: dungvu@nch.org.vn

Ngày nhận bài: 23.12.2020

Ngày phản biên khoa học: 23.2.2021

Ngày duyệt bài: 3.3.2021

\section{Nguyễn Trọng Thành*, Vũ Chí Dũng*}

case series study including clinical manifestations, history, cardiac function investigation, and treatment approach. Results: 2 out of 3 cases presented cardiogenic shock. Both of these patients presented with a reduction of cardiac contractile function, 2 out of 3 had prolonged QT in ECG. Blood tests revealed a severe reduction of calcium concentration and Vitamin $D$ deficiency. Conclusions: In these cases, hypocalcemia is the only cause that is found out to be associated with the clinical symptoms. Treatment with intravenous calcium, vitamin D supplement, calcitriol show to be effective to recover cardiac myocyte function.

Keywords: Hypocalcemia, Cardiogenic shock, Arrhythmias, Children.

\section{I. ĐĂT VẤN ĐỀ}

Ha canxi máu năng là một trong những cấp cứu thường gặp ở trẻ em. Tùy thuộc vào mức độ nặng của hạ canxi máu, trẻ có thể không có triệu chứng lâm sàng hoặc biểu hiện những triệu chứng lâm sàng nặng nề, ảnh hưởng đến chức năng sống của trẻ. Trong cơ thể, canxi đóng vai trò quan trọng giúp ổn định điện thế màng tế bào, tham gia vào hoạt động co bóp của cơ vân và cơ tim. Ớ tế bào cơ tim, giảm canxi máu làm giảm dòng canxi đi vào tế bào cơ tim trong giai đoạn điện thế hoạt động, từ đó dẫn đến giảm sức co bóp cơ tim, rối loạn nhịp tim, nặng hơn có thể dẫn đến sốc tim hoặc ngửng tim. Trên lâm sàng, sốc tim do hạ canxi máu là tình trạng nặng, nhưng có thể phục hồi nếu được phát hiện và xử trị kịp thời. Vì vậy, hạ canxi máu là một trong những nguyên nhân cân được chú ý và loại trừ khi tiếp cận chẩn đoán sốc tim ở trẻ em [1] [2].

Xuất phát từ những lý do trên, nghiên cứu được tiến hành với mục tiêu: mô tả đặc điểm lâm sàng, các triệu chứng tim mạch, chức năng tim và hướng xư trí ở những bệnh nhân có biến chứng tim mạch do hạ canxi máu nặng.

\section{II. ĐỐI TƯợNG VÀ PHƯƠNG PHÁP NGHIÊN CỨU}

Đối tượng gồm 3 trẻ nhập viện trong bệnh cảnh rối loạn chức năng tim mạch kèm theo hạ canxi máu năng. 2 trong 3 trường hợp được chẩn đoán sốc tim và 1 bệnh nhân được chẩn đoán giảm chức năng co bóp cơ tim nhưng chưa có sốc tim do hạ canxi máu nặng. 
Báo cáo loạt ca bệnh về tiền sử, bệnh sử, đặc điểm lâm sàng bao gồm: tuổi, giới, cân nặng, tuần thai khi sinh và các triệu chứng lâm sàng (co giật, kích thích - quấy khóc, bỏ bú hay li bì), chế độ ăn, tiền sử bệnh lý và bổ sung vi chất của mẹ trong thời kỳ mang thai. Mô tả đặc điểm cận lâm sàng gồm: khí máu, canxi (toàn phần và ion), điện giải đồ, phosphatase kiềm (ALP), phospho, PTH, vitamin $\mathrm{D}$, magie $(\mathrm{Mg})$, chức năng gan thận, protein toàn phần, albumin, điện tâm đồ, siêu âm tim, sàng lọc nhiễm khuẩn, FISH DiGeorge (nghi ngờ trên lâm sàng) và sàng lọc rối loạn chuyển hóa MS/MS (tandem mass spectrometry). Trong nghiên cứu, chúng tôi áp dụng 1 số tiêu chuẩn chẩn đoán và phân loại sau:

- Tiêu chuẩn hạ canxi máu: Nồng độ canxi ion trong máu thấp hơn $0,95 \mathrm{mmol} / \mathrm{l}$, hoặc nồng độ canxi toàn phần thấp hơn $1,9 \mathrm{mmol} / \mathrm{l}$, hoặc nồng độ canxi toàn phần trong máu ở giới hạn dưới và có biểu hiện triệu chứng lâm sàng [3].

- Tiêu chuẩn sốc tim: Hạ huyết áp với các dấu hiệu lâm sàng của giảm tưới máu mô bao gồm các dấu hiệu của thiểu niệu, tím tái, chi lạnh và thay đổi nhận thức. Những dấu hiệu này vẫn tồn tai sau khi đã được điều chỉnh giảm kali máu, rối loạn nhị tim, thiếu oxy và nhiễm toan [2].

- Mức độ thiếu vitamin D: Được phân loại theo "Khuyển nghị đồng thuận toàn cầu về phòng ngữa và quản lý bênh còi xương dinh dưỡng 2016" với 3 mức độ khi nồng độ Vitamin $D$ trong huyết thanh: nặng $(<12,5 \mathrm{nmol} / \mathrm{l})$, trung bình $(12,5-29 \mathrm{nmol} / \mathrm{l})$ và nhe $(30-49 \mathrm{nmol} / \mathrm{l})$ [3].

\section{KẾT QUẢ NGHIÊN CỨU}

Tổng số có 3 bệnh nhân được chẩn đoán hạ canxi máu nặng, trong đó có 2 bệnh nhân được chẩn đoán sốc tim và 1 bệnh nhân giảm chức năng co bóp cơ tim.

Bệnh nhân 1. Trẻ nữ, 3 tháng tuổi, con thứ nhất, đẻ thường, đủ tháng, cân nặng khi sinh $3,2 \mathrm{~kg}$, bú me hoàn toàn. Khoảng 2 ngày trước vào viên trẻ được tiêm phòng (không rõ loại). Sau tiêm phòng trẻ xuất hiện sốt, nhiệt độ 38,5 độ, quây khóc cơn, không phát ban, không ho. Từ sáng cùng ngày vào viện, trẻ sốt cao 39 độ, li bì, bỏ bú và co giật khoảng 2 cơn (co cứng 2 tay, duỗi 2 chân và mắt trợn ngược khoảng 1 phút). Trẻ khám cấp cứu tại Bệnh viện Nhi tuyến tỉnh được chẩn đoán: theo dõi sốc tim gồm các biểu hiện li bì, da xanh tái, thời gian làm đầy mao mạch (refill)> 4 giây, SpO2 83-84\%, nhịp tim nhanh, mạch yếu, tần số $200-220$ lần/phút, không ghi nhận nước tiểu. Xử trí đặt ống nội khí quản, trợ tim (Dopamin $10 \mathrm{mcg} / \mathrm{kg} /$ phút), kháng sinh và chuyển bệnh viện Nhi Trung ương trong tình trạng: Bóp bóng qua nội khí quản, phổi thông khí tốt, SpO2 95\%, da tái, mạch nhanh nhỏ, refill $>3$ giây, gan to $3-4 \mathrm{~cm}$ dưới bờ sườn, không có nước tiểu.

Tại bệnh viện Nhi Trung ương, bệnh nhân được siêu âm tim, điện tâm đồ và chụp Xquang lồng ngực tại giường. Siêu âm tim: Chức năng tâm thu thất trái giảm nặng với phân suất tống máu (EF) $28 \%$, tim trái giãn, không có dị tật tim bẩm sinh. Điện tâm đồ: Nhịp tim nhanh, tần số 210 lần/phút, QTc (corrected QT) kéo dài 0,5 giây (bình thường $<0,45$ giây). Xquang ngực: Bóng tim to (chỉ số tim ngực > $60 \%$ ).

Xét nghiệm hóa sinh (bảng 1): Toan chuyển hóa ( $\mathrm{pH}<7,21)$, hạ canxi máu nặng, thiếu vitamin D. PCR (Polymerase chain reaction) đa mồi virus gây viêm cơ tim cấp: Âm tính. Xét nghiệm dịch não tủy: Bình thường.

Chẩn đoán: Sốc tim do hạ canxi máu nặng thiếu Vitamin D

Điều trị: Thở máy, trợ tim (Dobutamin, Adrenalin), truyền canxi và magie tĩnh mạch, vitamin $\mathrm{D}$ và calcitriol đường uống.

Diễn biến: Trẻ được rút máy thở sau 2 ngày, chức năng cơ tim cải thiện (EF $58 \%$ ), hết rối loạn nhịp tim, tiểu tốt, không còn toan máu, canxi trong máu tăng lên.

Xét nghiệm máu mẹ: Vitamin $D$ 69,3 nmol/l (bình thường $>75 \mathrm{nmol} / \mathrm{l}$ ), canxi ion $0,84 \mathrm{mmol} / \mathrm{l}$ (bình thường $1,12-1,23 \mathrm{mmol} / \mathrm{l}$ ) và $\mathrm{PTH} 30,4$ ng/L (bình thường (11 - 79 ng/L). Mẹ không bổ sung vitamin $D$ và canxi đầy đủ trong thời kì mang thai.

Bệnh nhân 2. Trẻ trai, 17 ngày tuổi, được chẩn đoán suy tuyến cận giáp lúc 7 ngày tuổi. Trẻ là con thứ 3 , đẻ mố, đủ tháng, cân nặng lúc sinh 3,9 kg. Mẹ không được bồ sung canxi và vitamin $D$ trong thời kỳ mang thai, anh trai 3 tuổi được chẩn đoán suy tuyến cận giáp, hiện khỏe mạnh. Bệnh diễn biến 1 ngày, trẻ biểu hiện quấy khóc, sốt nhẹ, thở nhanh, bỏ bú và tím tái, trẻ được đi khám cấp cứu tại bệnh viện huyện, chẩn đoán: Viêm phổi suy hổ hấp - theo dõi rối loạn chuyển hóa (khóc yếu, tím môi, da nổi vân tím, SPO2 70-80\%, tim nhịp nhanh, mạch bắt yếu). Xử trí đặt ống nội khí quản và chuyển bệnh viện Nhi Trung ương trong tình trạng: li bì, không sốt, da tái, refill > 3 giây, phổi thông khí đều không có ran, $\mathrm{SpO} 2$ 97\%, tim nhịp nhanh, mạch bắt yếu, tần số 180 lần/phút.

Tại bệnh viện Nhi Trung ương, trẻ được siêu âm tìm, điện tâm đồ và chụp Xquang ngực tại giường. Điện tâm đồ: rối loạn nhịp tim với QTc 0,52 giây. Siêu âm tim: giãn toàn bộ các buồng 
tim và giảm nặng chức năng tâm thu thất trái với EF 43\%. Xquang ngực: chỉ số tim ngực > $70 \%$.

Xét nghiệm sinh hóa (bảng 1): toan chuyển hóa nặng ( $\mathrm{pH}<6,8)$, hạ canxi máu nặng, giảm vitamin $\mathrm{D}$, magie và $\mathrm{PTH}$.

Chẩn đoán: sốc tim do hạ canxi, magie máu suy tuyến cận giáp (với FISH DiGeorge không phát hiện mất đoạn trên nhiễm sắc thể 22q11.2).

Điều trị: Thở máy, trợ tim (Dobutamin, Mirinon), truyền canxi và magie tĩnh mạch, bổ sung vitamin $D$ và caltriol đường uống.

Diễn biến: Đáp ứng điều trị tốt, rút máy thở sau 3,5 ngày, chức năng tim cải thiện rõ rệt (không còn giãn các buồng tim, EF 70\%, hết rối loạn nhịp tim).

Bệnh nhân 3. Trẻ nam, 2 tháng tuổi, con thứ nhất, đẻ non 35 tuần, cân nặng khi sinh 1,9 kg, sau đẻ không suy hô hấp. Me trẻ ghi nhận trẻ thường có cớn khóc thét và cứng cổ kéo dài khoảng 2 phút, sau cơn trở lại bình thường. Bệnh lần này diễn biến 3 ngày, biểu hiện co cứng 2 tay, duỗi 2 chân, mắt trợn ngược, kéo dài 5 phút, $2-3$ cơn/ngày, sau cớn trẻ tỉnh, bú me bình thường. Bệnh nhân được đưa vào khoa cấp cứu Bệnh viện Nhi Trung ương: cơn co giật toàn thể kéo dài 3 phút, sau cơn trẻ tỉnh, không sốt, thóp không phồng, bú me tốt, tim nhịp đều, mạch rõ, tần số 150 lần/phút, SPO2 98\%, refill 2 giây, gan không to.

Xét nghiệm hóa sinh (bảng 1): hạ canxi máu nặng, không toan máu, thiếu vitamin $D$.

Siêu âm tim, điện tâm đồ: giảm chức năng tâm thu thất trái EF 55\%, không có rối loạn nhịp tim.

Chẩn đoán: hạ canxi máu nặng do thiếu vitamin $\mathrm{D}$ - giảm chức năng tâm thu thất trái.

Điều trị: truyền canxi tĩnh mạch, bổ sung vitamin $\mathrm{D}$, caltriol và canxi đường uống.

Diến biến: trẻ hết co giật, chức năng co bóp cơ tim trở về bình thường sau 5 ngày với $E F \quad 68 \%$.

Xét nghiệm máu mẹ: thiếu vitamin $D$ (36 $\mathrm{nmol} / \mathrm{l}$ ), canxi ion $0,95 \mathrm{mmol} / \mathrm{l}$ và $\mathrm{PTH} 30 \mathrm{ng} / \mathrm{L}$. Me không được bổ sung vitamin $D$ và canxi trong thời kỳ mang thai.

Bảng 3.1. Xét nghiệm hóa sinh máu của 3 bệnh nhân

\begin{tabular}{|c|c|c|c|c|}
\hline $\begin{array}{c}\text { Xét nghiệm } \\
\text { lúc vào } \\
\text { viện }\end{array}$ & $\begin{array}{c}\text { Beênnh } \\
\text { nhân 1 }\end{array}$ & $\begin{array}{c}\text { Beênnh } \\
\text { nhân 2 }\end{array}$ & $\begin{array}{c}\text { Bệnh } \\
\text { nhân 3 3 }\end{array}$ & $\begin{array}{c}\text { Trị số } \\
\text { bình } \\
\text { thường }\end{array}$ \\
\hline PH máu & 7,21 & $<6,8$ & 7,35 & $7,35-7,45$ \\
\hline $\begin{array}{c}\text { BE (Base } \\
\text { excess) }\end{array}$ & -11 & - & -1 & \\
\hline $\begin{array}{c}\text { Glucose } \\
\text { (mmol/l) }\end{array}$ & 16,5 & 18 & 8,6 & $3,3-5,5$ \\
\hline Lactate & 3,3 & $>15$ & 1 & $0,8-1,5$ \\
\hline
\end{tabular}

\begin{tabular}{|c|c|c|c|c|}
\hline (mmol/l) & & & & $2,1-2,55$ \\
\hline $\begin{array}{c}\text { Canxi tp } \\
\text { (mmol/l) }\end{array}$ & 0,76 & 0,82 & 0,86 & $\begin{array}{c}1,12- \\
1,23\end{array}$ \\
\hline $\begin{array}{c}\text { Canxi ion } \\
\text { (mmol/l) }\end{array}$ & 0,36 & 0,47 & 0,46 & $\begin{array}{c}1,46- \\
2,66\end{array}$ \\
\hline $\begin{array}{c}\text { Phospho } \\
\text { (mmol/l) }\end{array}$ & 1,83 & 1,68 & 1,45 & $0,6-0,95$ \\
\hline $\begin{array}{c}\text { Magie } \\
\text { (mmol/l) }\end{array}$ & 0,77 & 0,53 & 0,78 & $124-341$ \\
\hline ALP (IU/l) & 183 & 186 & 215 & 124 \\
\hline $\begin{array}{c}\text { Vitamin D } \\
(\mathrm{nmol} / \mathrm{l})\end{array}$ & 25 & 34 & 21 & $50-250$ \\
\hline PTH (pmol/l) & 38,25 & 1,1 & 23 & $11-79$ \\
\hline CRP (mg/dl) & 14 & 42 & 1,6 & $<6$ \\
\hline $\begin{array}{c}\text { ProBNP } \\
\text { (pmol/L) }\end{array}$ & 4876 & - & - & $<14,47$ \\
\hline $\begin{array}{c}\text { Troponin I } \\
\text { (ng/ml) }\end{array}$ & 0,85 & - & - & $<0,05$ \\
\hline
\end{tabular}

Canxi tp (Canxi toàn phần); ALP (Alkaline phosphatase); CRP (C reactive protein); PTH (Parathyroid hormon); (-): không xét nghiệm hoặc thấp không đo được.

\section{BÀN LUÂ̂N}

Nghiên cứu ghi nhân 3 trẻ nhỏ có triệu chứng sốc tim và giảm chức năng co bóp cơ tim. Duval và cộng sự (2018) nghiên cứu trên 155 trẻ có hạ canxi máu nặng có 3 trẻ $(2,0 \%)$ có biểu hiện sốc tim [4]; Newman năm 2014 báo cáo 3 bệnh nhân sốc tim trong 41 bệnh nhân hạ canxi máu nặng (7,3\%); Gupta và cộng sự năm 2011 ghi nhận 19\% [2]. Sự khác biệt tî lệ giữa các nghiên cứu là do khác nhau về đối tượng, cõ̃ mẩu và thời gian nghiên cứu.

Trên thế giới đã ghi nhận một số tác giả báo cáo những trường hợp rối loạn chức năng cơ tim do hạ canxi máu, có giảm sức bóp cơ tim, suy tim sung huyết và hạ huyết áp ở trẻ em [5]. Trong cơ thể, các chất điện giải đóng vai trò quan trọng đảm bảo chức năng cơ tim, đặc biệt là nồng độ canxi. Hạ canxi máu cấp tính gây kéo dài khoảng QT, có thể gây rối loạn nhịp thất. Trong nghiên cứu của chúng tôi, cả 3 trường hợp đều biểu hiện suy giảm chức năng co bóp cở tim, 2 bệnh nhân có giãn buồng tim phát hiện trên siêu âm tim. Trên điện tâm đồ, 2 bệnh giã̃n buồng tim có biểu hiện rối loạn nhịp với khoảng QTc kéo dài. Kết quả này tương đồng với nghiên cứu của một số tác giả khác. Gupta và cộng sự báo cáo 5 bệnh nhân có sốc tim do hạ canxi máu, biểu hiện tim mạch bao gồm giảm chức năng tâm thu thất trái (EF trung bình $15 \%$ ), giãn buồng tim và khoảng QTc kéo dài [2]. Gulati báo cáo trường hợp trẻ 4 tháng tuổi chẩn đoán sốc tim có giãn buồng tim và QTc kéo dài [5]. 
Thiếu vitamin $D$ là nguyên nhân chủ yếu của hạ canxi máu ở trẻ sơ sinh và trẻ nhỏ. Maiya và cộng sự báo cáo loạt 16 ca bệnh cơ tim ở trẻ em có liên quan đến thiếu vitamin $D$ dẫn đến hạ canxi máu [6]. 3 trường hợp trong nghiên cứu của chúng tôi đều thiếu vitamin $D$ mức độ trung bình; trong đó, 1 trẻ đã được chẩn đoán suy tuyến cận giáp (PTH máu 1,1 pmol/l). Suy tuyến cận giáp cũng là nguyên nhân gây hạ canxi máu nặng và suy tim [7]. Dự trữ vitamin $\mathrm{D}$ của thai nhi và trẻ sơ sinh phụ thuộc vào tình trạng vitamin $D$ của me [8]. Mẹ của những trẻ này đều bị thiếu vitamin $D$ (tất cả $<75 \mathrm{nmol} / \mathrm{l}$ ) và không được bổ sung vitamin $\mathrm{D}$, canxi trong thời kỳ mang thai. Do đó, phụ nữ mang thai cần bổ sung vitamin $D$ dự phòng. Điều trị sốc tim do ha canxi máu gồm hỗ trợ chức năng cơ tim và bổ sung canxi. Hai bệnh nhân sốc tim và nhiễm toan chuyển hóa được điều trị hỗ trợ bằng thuốc trợ tim - vận mạch và thở máy. Bệnh nhân thứ 3 được phát hiện và điều trị kịp thời chưa có biểu hiện sốc tim trên lâm sàng. Những bệnh nhân này đều được điều trị bằng canxi và vitamin $D$ cho kết quả tốt với phục hồi chức năng cơ tim và hết rối loạn nhịp tim. Tomar và cộng sự báo cáo một loạt ca bệnh gồm 15 trẻ sơ sinh được chẩn đoán bệnh cơ tim do hạ canxi máu, đáp ứng tốt với điêu trị bằng vitamin $\mathrm{D}$ và canxi, chức năng cơ tim đã trở lại bình thường trong vòng vài tháng[9]. Biểu hiện lâm sàng, xét nghiệm hóa sinh và đáp ứng tốt với điều trị hạ canxi máu giúp khẳng định nguyên nhân hạ canxi máu nặng gây ra sốc tim.

\section{KẾT LUẬN}

Sốc tim là tình trạng nặng có thể gặp do hạ canxi máu. Nguyên nhân chủ yếu của hạ canxi máu là thiếu Vitamin $D$, bên cạnh đó suy tuyến cận giáp cũng là nguyên nhân cần chú ý. Điều trị kịp thời sốc tim do hạ canxi máu bằng bổ xung canxi và vitamin $D$ mang lại hiệu quả tích cực và có thể hồi phục hoàn toàn. Bổ sung Vitamin $\mathrm{D}$ cho me trong thời kỳ mang thai, cho con bú và dự phòng vitamin $\mathrm{D}$ cho trẻ sơ sinh là biện pháp cần thiết.

\section{TÀI LIÊU THAM KHẢO}

1. Elidrissy A.T.H., Munawarah M., Alharbi K.M. (2013). Hypocalcemic rachitic cardiomyopathy in infants. Journal of the Saudi Heart Association, 25(1), 25-33.

2. Gupta P., Tomar M., Radhakrishnan S. et al. (2011). Hypocalcemic cardiomyopathy presenting as cardiogenic shock. Ann Pediatr Cardiol, 4(2), $152-155$.

3. Munns C.F., Shaw N., Kiely M. et al. (2016). Global consensus recommendations on prevention and management of nutritional rickets. J Clin Endocrinol Metab, 101(2), 394-415.

4. Duval M., Bach-Ngohou K., Masson D. et al. (2018). Is severe hypocalcemia immediately life threateninq?. Endocr Connect, 7(10), 1067-1074.

5. Gulati S., Bajpai A., Juneja R. et al. (2001). Hypocalcemic heart failure masquerading as dilated cardiomyopathy. Indian J Pediatr, 68(3), 287-90.

6. Maiya S., Sullivan I., Allgrove J. et al. (2008). Hypocalcaemia and vitamin D deficiency: an important, but preventable, cause of life-threatening infant heart failure. Heart, 94(5), 581-584.

7. Altunbaş H., Balci M.K., Yazicioğlu G., et al. (2003). Hypocalcemic cardiomyopathy due to untreated hypoparathyroidism. Horm Res, 59(4), 201-204.

8. Hollis B.W., Waqner C.L. (2004). Assessment of dietarv vitamin $D$ requirements durina pregnancy and lactation. Am J Clin Nutr, 79, 717-726.

9. Tomar M., Radhakrishnan S., Shrivastava S. (2010). Myocardial dysfunction due to hypocalcemia. Indian Pediatr, 47(9), 781-783.

\section{ĐĂC ĐIỂM MộT SỐ YẾU TỐ LIÊN QUAN ĐẾN BỆNH SINH SUY THÂ̂N MẠN TÍNH Ở ĐỐI TƯỢNG GHÉP THẬN}

\section{TÓM TẮT}

Mục tiêu: Phân tích các yếu tố tiền sử và các yếu tố nguyên nhân dẫn đến suy thận mạn tính và tî lệ

\footnotetext{
${ }^{1}$ Bệnh viện Quân y 103

${ }^{2}$ Hoc viên Quân y

Chịu trách nhiệm chính: Đặng Thành Chung

Email: dangthanhchung@vmmu.edu.vn

Ngày nhận bài: 29.12.2020

Ngày phản biện khoa học: 19.2.2021

Ngày duyệt bài: 1.3 .2021
}

\begin{abstract}
Nguyễn Đức Thuận ${ }^{1}$, Đặng Thành Chung²
các giai đoạn của bệnh thận mạn tính trên đối tượng 3 tháng sau ghép thận. Đổi tượing và phương pháp nghiên cứu: Gồm 508 bệnh nhân có thời gian sau ghép thận $\geq 3$ tháng được theo dõi và điêuu trị sau ghép tại BV Việt Đức, từ 09/2017 đến 04/2018. Tất cả các bệnh nhân đều tự nguyện tham gia nghiên cứu. Khai thác các thông tin tiên sử các bệnh lý gây ra suy thân mạn. Tiến hành hồi cứu bệnh àn phát hiện các yếu tố nguy cơ hoăc là nguyên nhân gây suy thận mạn. Đánh giá phẩn giai đoạn bệnh thận mạn tính sau ghép theo KDIGO 2012. Kết quả: Nhóm đối tượng có tiền sử tăng huyết áp có tỉ lệ cao nhất chiếm
\end{abstract}

